\title{
KAJIAN STRUKTUR DRAMATIK PADA FILM MURSALA KARYA VIVA WESTI
}

\author{
Sri Wahyuni,, Rosta Minawati,, Febri Yulika \\ Prodi Televisi dan Film Universitas Potensi Utama Medan \\ Prodi Televisi dan Film Institut Seni Indonesia (ISI) Padangpanjang \\ Institut Seni Indonesia (ISI) Padangpanjang \\ sriwahyuni2909@gmail.com rostaminawati@yahoo.co.id, febri.isipp@gmail.com
}

\begin{abstract}
ABSTRAK
Tujuan penulisan ini adalah mengungkap struktur dramatik pada film Mursala. Film Mursala memuat unsur naratif yang membentuk susunan peristiwa dan saling memiliki hubungan satu dengan yang lainnya serta adanya keterikatan dalam logika sebab akibat (kausalitas) yang terjadi dalam ruang dan waktu. Untuk mengungkap struktur dramatik film Mursala, maka digunakan pendekatan struktural dengan metode analisis deskriptif.Film Mursala bercerita mengenai larangan pernikahan se-marga pada masyarakat Batak. Batak merupakan salah satu suku bangsa Indonesia yang menjunjung tinggi adat dan nilai kekeluargaan (kekerabatan). Suku Batak juga memiliki aturan-aturan tertentu yang harus ditaati, termasuk tentang pemilihan pasangan hidup, siapa yang dapat dinikahi dan tidak dapat dinikahi. Pertentangan terhadap adat dalam isi cerita film Mursala menyebabkan adanya konflik dari awal hingga bagian klimaks dari cerita. Maka pendekatan strukturalisme (exposition, complication, climax, reversal dan denoument) digunakan untuk mengetahui kronologi cerita, tokoh/penokohan hingga klimaks yang dituangkan dalam permasalahan serta tahap akhir cerita yang merupakan kesimpulan untuk menjelaskan alur dramatik.
\end{abstract}

Kata Kunci : Struktur Dramatik, Film Mursala, Adat Batak

\begin{abstract}
The purpose of this paper is to reveal the dramatic structure of the film Mursala. Mursala's film contains a narrative element that shapes the order of events and has a relationship with one another and there is an attachment to the logic of cause and effect (causality) that occurs in space and time. To uncover the dramatic structure of the Mursala film, a structural approach with a descriptive analysis method is used. The Mursala film tells about the prohibition of marriage of all people in the Batak community. Batak is one of the ethnic groups of Indonesia that upholds the customs and values of kinship (kinship). The Batak tribe also has certain rules that must be obeyed, including the choice of a life partner, who can be married and cannot be married. Opposition to adat in the content of the Mursala film causes conflicts from the beginning to the climax of the story. Then the structuralism approach (exposition, complication, climax, reversal and denoument) is used to find out the chronology of the story, characters / characterizations to the climax that is outlined in the problem and the final stage of the story which is a conclusion to explain the dramatic flow.
\end{abstract}

Keywords: Dramatic Structure, Mursala Movie, Batak Custom. 


\section{PENDAHULUAN}

Mursala merupakan sebuah pulau terbesar yang berada di wilayah kabupaten Tapanuli Tengah, pulau ini termasuk wilayah kecamatan Barus, Tapanuli Tengah dan terletak di sebelah Barat Daya Kota Sibolga. Pulau Mursala dijadikan sebuah film bergenre drama dengan durasi sekitar I jam 30 menit 6 detik dan diberi nama denganfilm Mursala yang disutradarai oleh Viva Westi. Tema yang termuat dalam film Mursala adalah perjuangan dari seorang pemuda Batak bernama Anggiat yang diperankan oleh Rio Dewanto.Anggiat merantau ke Jakarta dari kampungnyaSorkam, Tapanuli Tengah dan menjadi pengacara yang sukses.Ibunya Inang $^{l}$ Romauli dan ayahnya Amung ${ }^{2}$ Hotman mengharapkan Anggiat menikah dengan pariban-nya ${ }^{3}$. Akan tetapi di Jakarta Anggiat telah memiliki wanita berdarah Batak yang dicintainya yaitu Clarisa (Anna Sinaga), seorang presenter televisi. Persoalan muncul ketika ternyata Anggiat dan Clarita terjebak dengan aturan adat Batak, yang membuat mereka tidak dapat menikah. Adapun cover film mursala karya Viva Westi sebagai berikut :

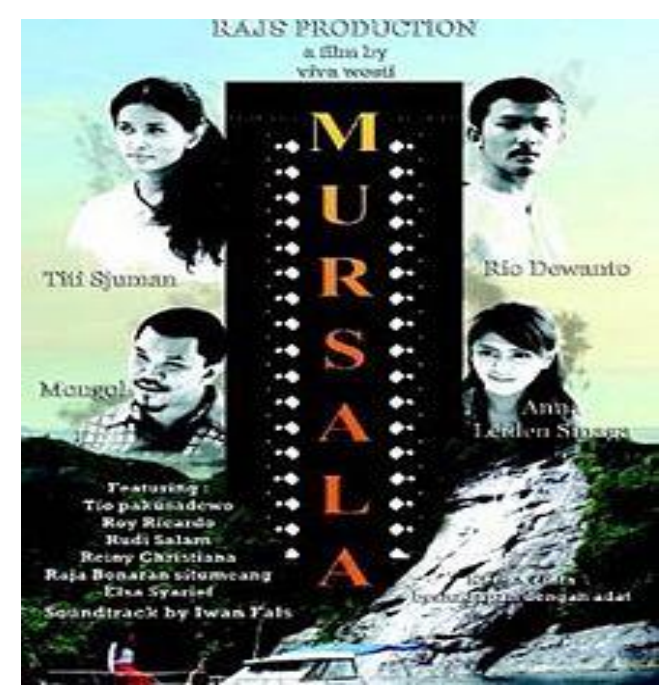

Gambar 1. Cover Film Mursala

(Sumber. Wikipedia. Capture Cover Film Mursala. 2017)

Cerita pada film Mursala memuat unsur naratif yang membentuk susunan peristiwa dan saling memiliki hubungan satu dengan yang lainnya serta adanya keterikatan dalam logika sebab akibat (kausalitas) yang terjadi dalam ruang dan waktu. Cerita pada Film Mursala memunculkan akibat aksi, tindakan dari pelaku cerita yang memotivasi terjadinya kesatuan peristiwa yang memuat unsur-unsur plot. Menurut Haig P. Manoogian alur cerita (plot) merupakan penggambaran cerita dalam sebuah film, yang terdiri dari runtutan kejadian yang memiliki motivasi dan hubungan secara sebab akibat. Struktur menunjuk kepada kejadian-kejadian dari plot tersebut (Paransi, 2005: 8).

Rangkaian peristiwa ini memiliki struktur dramatik yang mengikat perkembangan dan ada kaitannya antar konflik dari awal cerita hingga akhir. Struktur dramatik menurut Gustav Freytag terdiri dari expositions sebagai pengenalan karakter dengan masalah yang digulirkan, penonton diberikan informasi mengenai masalah yang terjadi pada tokoh utama. Complication atau perumitan masalah, pada tahap ini mulai dijelaskan laku karakter dalam mengatasi konflik yang tidak mudah untuk mengatasinya sehingga akan timbul rasa

\footnotetext{
${ }^{1}$ Inang adalah panggilan ibu dalam bahasa Batak

${ }^{2}$ Amung adalah panggilan ayah dalam bahasa Batak

${ }^{3}$ Pariban adalah saudara sepupu dalam suku Batak yang dapat di miliki
} 
frustasi, amukan, ketakutan, kemarahan. Konflik ini semakin rumit sehingga membuat karakter-karakter akan semakin merasa tertekan serta terus berusaha untuk keluar dari konflik tersebut. Climax atau puncak laku, pada tahapan ini semua persoalan dan masalah akan terurai satu persatu dan mendapatkan informasi melalui laku karakter serta lewat dialog yang akan disampaikan oleh peran. Reversal sebagai penurunan emosi lakon, namun bukan hanya berlaku kepada lakon tetapi juga kepada penonton. Denoument digunakan sebagai penyelesaian akhir happy ending atau unhappy ending. Penuturan dramatik mempunyai dasar setiap cerita yang tidak hanya pada awal, tengah dan akhir tetapi juga harus melibatkan dua bentuk tahapan dalam plot utama yaitu tahap complication (kerumitan) dan tahap denoument (menyelesaikan kerumitan) (Herymawan, 1988:20).

Berdasarkan struktur dramatik pada film Mursala terdapat makna yang ditentukan dari rangkaian peristiwa yang mengikat kondisi psikologis tokoh utama, aspek sosial dan frame work budaya yang tergambar dalam film Mursala. Keadaan yang dapat mempengaruhi arti dari tanda yang menyangkut kondisi psikologis yaitu kesedihan, kebingungan, ketakutan, kesedihan dan kesabaran. Keadaan yang dapat memengaruhi arti dari tanda yang menyangkut kondisi sosial yaitu persahabatan, percintaan, kesopanan, kejujuran, pertentangan, keadilan dan kesederhaan. Sedangkan keadaan yang memengaruhi arti dari penandaan frame work budaya yaitu musyawarah dan mufakat, merantau dan pekerja keras.

Penelitian ini menggunakan metode analisis deskriptif dengan pendekatan strukturalisme yang memfokuskan kepada struktur dramatik dari film Mursala. Analisis deskriptif bertujuan agar hasil analisa masalah yang diperoleh, dapat diinterpretasikan secara jelas melalui langkah-langkah metode penelitian yang sesuai. Agar mendapatkan hasil yang tepat dan sesuai dengan rumusan masalah, tujuan dan manfaat penelitian, maka dibutuhkan beberapa item metode dalam melakukan penelitian yang harus ditentukan pada proses analisis. Landasan teori dalam penelitian ini menggunakan teori struktur dramatik Gustav Freytag yang menyebutkan lima elemen dalam menggambarkan dramatik dalam sebuah cerita. Lima elemen Gustav Freytag yaitu exposition, complication, climax, reversal dan denoument(Herymawan, 1988:20). Selain itu untuk merumuskan secara sistematis penganalisaan sebuah tanda dalam masyarakat digunakan analisis struktural. Tanda yang ada dalam masyarakat dapat berkaitan pada kondisi psikologis, aspek sosial dan frame work budaya (sign, signifier dan signified) (Ferdinand de Saussure,1857-1913).

\section{PEMBAHASAN}

Cerita sebuah film memuat unsur naratif yang membentuk susunan peristiwa dan saling memiliki hubungan satu dengan yang lainnya serta adanya keterikatan dalam logika sebab akibat (kausalitas) yang terjadi dalam ruang dan waktu. Cerita pada Film Mursala memunculkan akibat aksi, tindakan dari pelaku cerita yang memotivasi terjadinya kesatuan peristiwa yang memuat unsur-unsur plot. Plot merupakan rangkaian peristiwa yang disajikan secara audio visual dalam film (Pratista, 2008: 33). Sedangkan plot Menurut Haig P. Manoogian merupaka Alur cerita (plot) adalah penjabaran dari cerita sebuah film, terdiri dari rentetanrentetan kejadian bermotivasi dan berhubungan secara sebab akibat. Struktur menunjuk kepada kejadian-kejadian dari plot tersebut (Paransi, 2005: 8).

Plot sebagaian besar dituturkan dalam pola linier dimana urutan waktu berjalan sesuai urutan aksi peristiwa tanpa adanya interupsi waktu yang signifikan. Elemen-elemen naratif yang membantu jalannya sebuah alur cerita adalah pelaku cerita yang menjadi motivator utama yang menjalankan alur cerita seperti tokoh protagonis (utama/jagoan) dan antagonis (pendukung/musuh/rival). Permasalahan/konflik, dapat diartikan seperti penghalang tokoh 
protagonis untuk mencapai tujuannya. Tujuan yang ingin dicapai pelaku cerita, bisa berupa fisik seperti mengalahkan musuh atau dapat berupa non fisik seperti kebahagiaan dan sebagainya (Pratista, 2008: 44).

Dengan demikian, pelaku cerita sebagai penggerak cerita yang menjalankan alur naratif sejak awal hingga akhir cerita. Tokoh utama dapat diistilahkan sebagai pihak protagonis sedangkan karakter pendukung dapat berada dipihak protagonis atau antagonis sebagai pemicu adanya konflik, dalam hal ini tokoh utamanya adalah Anggiat Simbolon yang diperankan oleh Rio Dewanto. Anggiat adalah seorang pemuda yang berasal dari Desa Sorkam Kabupaten Tapanuli Tengah. Anggiat berperan sebagai tokoh pemuda Batak yang berasal dari Desa Sorkam dan merantau ke Kota Jakarta untuk menggapai cita-citanya sebagai pengacara. Perjuangan Anggiat tidak sia-sia karena di Jakarta Anggiat berhasil menjadi pengacara yang sukses. Di Jakarta Anggiat sudah mempunyai kekasih yang juga berketurunan Batak bernama Clarisa Saragih yang diperankan oleh Anna Sinaga. Namun, persoalan atau pertentangan timbul karena Inang Anggiat ingin putranya menikah dengan Pariban-nya yaitu Tarulli Sinaga yang berada di kampungnya.

Pertentangan ini yang menjadi inti sebuah drama yang disebut dengan istilah konflik (Mark, 1985: 41). Konflik merupakan dasar pada sebuah drama yang berupa pertentangan yang terjadi pada tokoh sebagai respon atas timbulnya kekuatan-kekuatan dramatis (Dietrich, 1953: 78). Film Mursala sendiri bergenre drama, yang pada dasarnya drama berarti pencerminan dalam kehidupan manusia di masyarakat. Dalam cerita kehidupan masyarakat tentunya manusia memiliki pertentangan-pertentangan ataupun permasalahanpermasalahan baik fisik maupun psikis seperti tokoh Anggiat yang ingin menentang adat larangan menikah se-marga. Menurut Mark drama yang baik umumnya memiliki konflik yang selalu mempunyai keterkaitan antara tema dan alur, tema terbangun melalui alur yang kuat dan alur tersebut dapat menarik perhatian karena tersusun dengan jalinan konflikkonflik yang matang dan terarah serta tersebar secara merata dalam setiap alur tersebut (Mark, 1985: 85).

Dengan demikian yang dimaksud dengan konflik dalam film Mursala adalah satu komplikasi yang bergerak pada satu klimaks atau bagian alur yang menggambarkan pertentangan-pertentangan yang di alami tokoh, maupun pertentangan-pertentangan yang terjadi pada tokoh yang lain, hal ini di maksudkan sutradara untuk memberikan penggambaran kepada penonton supaya penonton dapat menduga-duga dan penasaran terhadap perkembangan cerita selanjutnya. Struktur dramatik yang mengandung alur/plot pada film Mursala dari awal hingga akhir. Adapun struktur dramatik pada film Mursala sebagai berikut:

\section{Exposition (Eksposisi)}

Tahap eksposisi bertujuan untuk penggambaran awal dari sebuah tokoh, memperkenalkan karakter para tokoh, reaksi antar pelaku, penggambaran fisik dan penggambaran tempat dalam sebuah film. Penggambaran tersebut membentuk sebuah alur pada sebuah film yang memberikan penonton informasi tentang cerita yang akan disampaikan. Pada tahap ini sutradara juga memberikan informasi atasmasalah yang dialami atau konflik yang terjadi dalam karakter yang ada dalam naskah.

Tahap eksposisi dalam film Mursala dimulai dengan pengenalan tokoh Anggiat dan Uli serta hubungan emosional yang ada diantara keduanya. Gambaran tersebut dapat dilihat pada scene 1-14:

Skenario film Mursala : scene 1-7

2. INT.SEKOLAH-PAGI

3. EXT.PANTAI.SIANG

5. EXT.PINGGIR JALAN. SIANG 


\section{EXT. MOBIL PICK UP.SIANG}

\section{INT.SEBUAH KAFE. SIANG}

Pada scene 5, Inang (Ibu Anggiat) mengajak Anggiat untuk pulang kerumahnya menggunakan mobil pick up. Terlihat Anggiat bersama Sahat berada dimobil tersebut, kemudian dalam shot selanjutnya Inang mengendarai sambil menyanyikan lagu Batak yang berjudul "Argado Bonani Pinasa" dalam perjalanan pulang bersama Anggiat dan Sahat. Secara bersamaan Inang melihat Uli di pinggir jalan dan memanggilnya untuk ikut dengannya dan mengantarnya pulang. Anggiat membantu Uli untuk naik ke mobil, Anggiat menatap wajah Uli. Sahat yang melihatnya kemudian mencoba bergurau dengan menggoda Anggiat dengan berkata:

Ciyeeee....

Kenapa kau lihat-lihat si Uli itu terus-terus.. Anggiat pun menjawab dengan jawaban :

Siapa yang lihat-lihat...

Disisi lain, setelah dewasa Anggiat merantau ke Jakarta untuk menjadi pengacara yang sukses dan memiliki kekesih bernama Clarisa Saragih.Salah satu capture scene yang memperlihatkan hubungan Anggiat dan Uli serta hubungan Anggiat dengan Kekasihnya Clarisa yaitu:
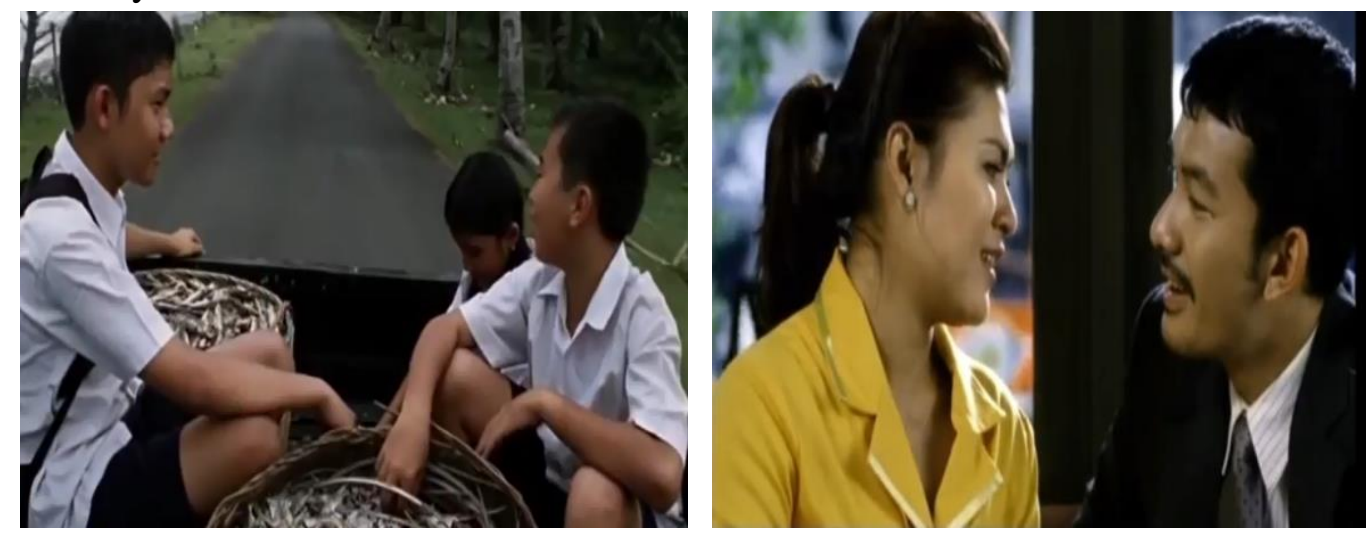

Gambar 2. Anggiat bersama Uli dan Anggiat bersama Clarisa

(Sumber. Sri Wahyuni. Capture Film Mursala. 2017)

Pada Gambar 1 terlihat kedekatan Anggiat dengan Uli pariban-nya ketika masih duduk di bangku sekolah SMP yang berada di kampungnya yaitu Sorkam. Namun setelah Anggiat merantau ke Jakarta ternyata dirinya telah mendapatkan seorang kekasih yang juga berdarah Batak dan berprofesi sebagai reporter televisi yaitu Clarisa Saragih. Gambar 1 juga menjelaskan hubungan Anggiat dan Clarisa, ketika Clarisa telah selesai mewawancari Anggiat mengenai kasus sandal jepit yang menimpa seorang anak yaitu Rois yang sedang ditangani oleh Anggiat. Selayaknya seorang kekasih, Clarisa mengungkapkan keletihannya menjalani profesi sebagai reporter kepada Anggiat.

\section{Complication (Perumitan)}

pada tahap ini mulai dijelaskan laku karakter dalam mengatasi konflik yang tidak mudah untuk mengatasinya sehingga akan timbul rasa frustasi, amukan, ketakutan, kemarahan. Konflik ini semakin rumit sehingga membuat karakter-karakter akan semakin merasa tertekan serta terus berusaha untuk keluar dari konflik tersebut.

Tahap complication ini terjadi kerumitan antara hubungan Anggiat dan Clarisa. Kedua orang tua Anggiat terkejut ketika mengetahui bahwasanya marga Clarisa adalah Saragih. 
Ibu Anggiat mencari tahu mengenai asal usul keluarga Clarisa dan di sela-sela pertanyaannya mengenai Clarisa, Inangkemudian menanyakan pendapat Anggiat mengenai Uli pariban-nya. Tiba-tiba Duma (Adik Anggiat) masuk kedalam rumah dan mengatakan bahwa Anggiat dan Clarisa tidak dapat menikah karena marga yang berada dalam satu parna. Anggiat pun merasa terkejut mendengar larangan tersebut, dengan ekspresi yang ditampilkan menunjukkan Anggiat tidak mengetahui hal tersebut. Peristiwa tersebut dapat dilihat dari scene sebagai berikut:

Skenario film Mursala :scene 21-31

25. EXT.GEREJA-SIANG

29. INT.HALAMANGEREJA.SIANG

31. INT. RUMAH.SIANG

Gambaran terjadinya perumitan masalah terlihat dari kutipan naskah sebagai berikut:

31. INT. RUMAH.SIANG

DUMA

Inang, Inang sudah bilang sama bang Anggiat. Kalau dia dan kak Clarisa kan nggak bisa bersama karena Simbolon dan Saragih kan tidak bisa menikah. Kena parna bang, sudah pusing Inang memikirkan abang tentang parnaitu.

Dari kutipan tersebut Duma memberitahukan Anggiat bahwasanya Anggiat dan Clarisa tidak dapat menikah karena termasuk dalamparna ${ }^{4}$. Anggiat yang tidak mengetahuinya merasa bingung tentang adat tersebut. Anggiat tetap melanjutkan hubungannya dengan Clarisa kekasihnya. Berikut capture scene 31 ketika Duma memberitahu Anggiat mengenai parna:

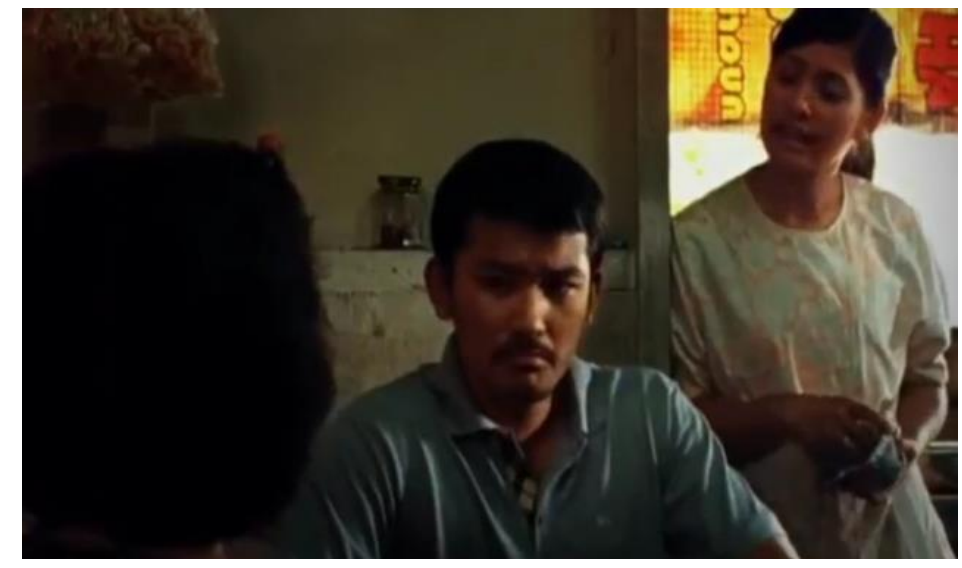

Gambar 3. Duma memberitahu Anggiat mengenai parna (Sumber. Sri Wahyuni. Capture Film Mursala. 2017)

Pada Gambar 2 Duma memberitahukan mengenai parna kepada Anggiat serta kegelisahan Inang yang tidak dapat mengungkapkannya kepada Anggiat. Anggiat yang sudah lama tinggal di Kota Jakarta membuatnya tidak tau mengenai adat dalam masyarakat Batak.

\section{Climax (Puncak Laku)}

\footnotetext{
${ }^{4}$ Parna merupakan kumpulan beberapa marga yang dipercaya sebagai Keturunan Raja Naimbaton atau disibeut dengan istilah "Pomparan ni si Raja Naimbaton" yang disingkat dengan Parna. Marga-marga yang termasuk kedalam keturunan Parna ini tidak diperbolehkan untuk menikah satu sama lain karena masih dianggap satu saudara sebagai putri-putri Naimbaton.
} 
Tahap ketiga yang menjadi bagian dari plot/alur yaitu klimaks atau puncak laku. pada tahapan ini semua persoalan dan masalah akan terurai satu persatu dan mendapatkan informasi melalui laku karakter serta lewat dialog yang akan disampaikan oleh peran. Jadi penonton dapat mengerti dengan permasalahan yang dihadapi tokoh melalui laku karakter ataupun dialog yang disampaikan. Film Mursala menguraikan permasalahan melalui tokoh Anggiat yang bingung mengenai larangan pernikahan karena adat dan ingin mencari tahu mengenai parna tersebut. Peristiwa-peristiwa tersebut dapat dilihat dari:

Skenario film Mursala : scene 40-59

43. INT.SEBUAH WARUNG-SIANG

56. INT.KAMAR HOTEL.SIANG

57. INT.SEBUAHCAFE.SIANG

58. INT.GEREJA.SIANG

Anggiat berdiskusi dengan keluarga dan Penasihat Adat Batak untuk menanyakan mengenai parna yang sedang menjadi masalah bagi hubungan Anggiat dan Clarisa. Anggiat yang sama sekali tidak tahu mengenai adat merasa keberatan dengan adanya adat tersebut karena menurutnya tidak ada hubungan antara adat dan hubungan pernikahan. Menurut Anggiat tanpa adanya bukti tertulis bahwa ada larangan pernikahan bagi seseorang berketurunan Batak yang termasuk dalam parna, dirinya merasa tidak percaya. Namun, keluarga dan penasihat adat menjelaskan kembali bahwa parna telah diwariskan oleh leluhur kepada secara turun temurun oleh masyarakat Batak sejak dahulu. Dan untuk menghargai para leluhur pasangan yang masuk kedalamparna tidak boleh menikah satu sama lain.

Disisi lain, Clarisa yang bertemu dengan Inang merasa kecewa atas penjelasan bahwasanya dirinya tidak dapat menikah dengan Anggiat. Clarisa yang terlahir di ibu kota tidak mengetahui mengenai adat Batak, meskipun Clarisa bersuku Batak. Hal itu yang membuatnya kecewa karena Clarisa dan Anggiat telah merencanakan untuk menikah namun hal itu harus dibatalkan karena adanya larangan tersebut. Berikut capture salah satu scene yang menggambarkan Anggiat marahsebagai berikut:

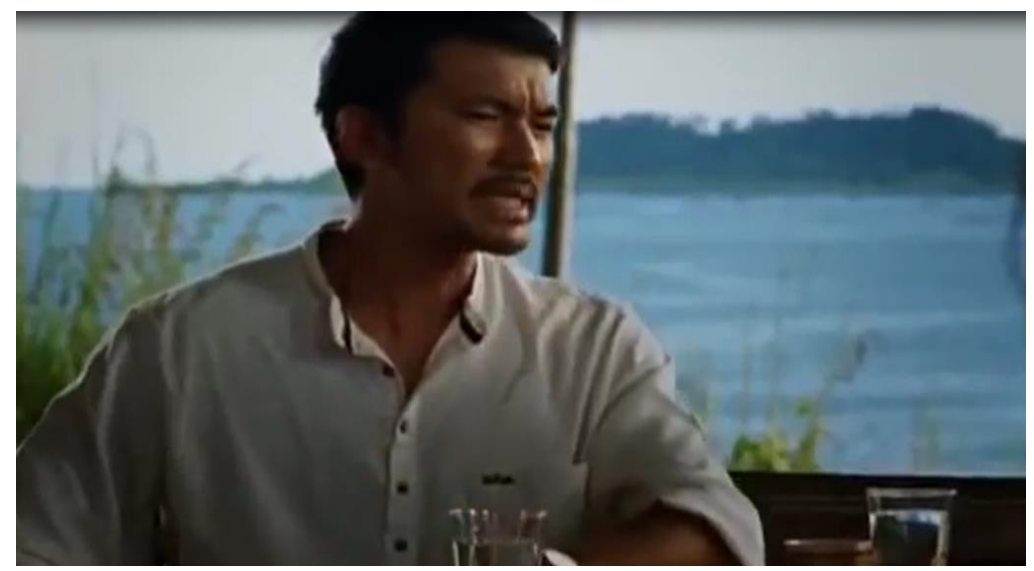

Gambar 4. Anggiat emosi pada saat bertemu dengan Penasihat adat (Sumber. Sri Wahyuni. Capture Film Mursala. 2017)

Pada Gambar 4 menjelaskan emosi Anggiat yang memuncak sampai dirinya memukul meja. Anggiat tidak terima dengan adanya adat tersebut karena merasa adat tersebut tidak masuk dalam logika. Sebagai pengacara sukses yang merantau di kota, menurut pandangan Anggiat seseorang bisa saja berkenalan dengan bermacam suku budaya atau berbagai 
margayang ada pada masyarakat Batak. Namun, emosi Anggiat tidak dapat merubah adat yang sudah lama diwariskan secara turun temurun oleh masyarakat Batak Toba karena dengan tidak menikah dengan se-parna-nya maka orang tersebut dianggap telah menghormati leluhurnya.

\section{Reversal / Penurunan Emosi (Falling Action)}

Pada tahap ini terjadi penurunan emosi para tokoh dan penokohan. Hal ini terjadi bukan saja sebagai penurunan emosi lakon, tetapi juga kepada penonton. Sejak awal emosi penonton sudah diajak naik dan turun kemudian dipermainkan. Selain itu, Falling Action juga berfungsi sebagai jeddah waktu bagi penonton dalam merenungkan apa yang sudah ditonton. Titik ini biasanya ditandai oleh semakin lambatnya emosi permainan, dan volume suara pemeran lebih bersifat menenangkan.

Anggiat mencari solusi atas permasalahan yang dihadapi. Anggiat bertemu dengan Uli di pantai sambil membicarakan mengenai hubungannya dengan Clarisa. Uli sebagai pariban (sepupu yang boleh dinikahi) memberikan saran kepada Anggiat dan tidak ingin mengambil keuntungan dari permasalahan yang dihadapi Anggiat. Namun, disisi keikhlasan Uli ketika Anggiat memilih mempertahankan hubungannya dengan Clarisa, Uli terlihat kecewa. Anggiat ingin menentang adat yang melarangnya menikah dengan Clarisa. Inang yang tahu kemudian merasa kecewa dan menangis karena jika Anggiat menentang adat maka Anggiat akan di keluarkan dari adat Batak dan dapat berdampak pada pengusiran. Anggiat mencoba menemui ayah Clarisa dan meminta restu darinya, namun ayah Clarisa juga tidak dapat merestuinya dan menentang adat. Clarisa yang tidak ingin menyakiti hati orang tua Anggiat memilih pergi ke luar negeri untuk melanjutkan kuliah magister nya. Peristiwa-peristiwa tersebut dapat dilihat dari:

Skenario film Mursala : scene 64-85

64. EXT.PANTAI-SIANG

75. INT.RUMAH CLARISA.SIANG

77. INT.BASECAMP ULI.SIANG

78. INT.RUMAH CLARISA.SIANG

Berikut capture salah satu scene yang menggambarkan reversal sebagai berikut:

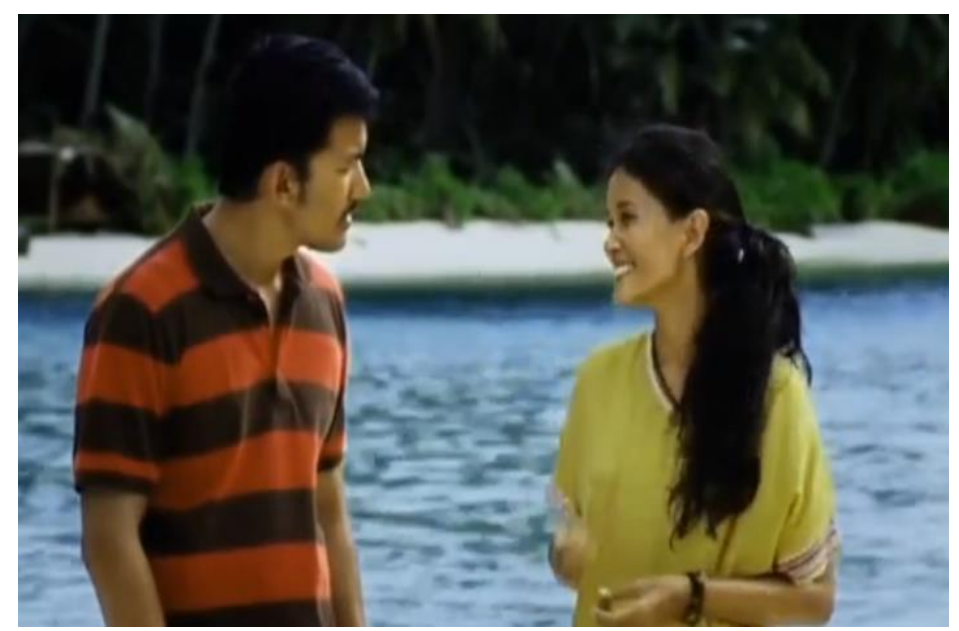

Gambar 5. Anggiat menemui Uli untuk mencari solusi (Sumber. Sri Wahyuni. Capture Film Mursala. 2017) 
Pada Gambar 4 terlihat Anggiat dan Uli berada di sebuah Pantai. Anggiat mengingat masa kecilnya bersama Uli yang sempat memberikan kerang bermotif kepada Uli sebelum meminta perndapat Uli mengenai masalahnya. Pada sceneini Anggiat yang pada awalnya sangat optimis untuk mempertahankan Clarisa walaupun ditentang oleh adat Batak menjadi ragu dan terlihat bimbang. Hal itu terlihat dari pertanyaan-pertanyaan yang disampaikan oleh Uli. Anggiat meminta pendapat Uli mengenai parna dan paribanuntuk menghilangkan keraguannya dalam pengambilan keputusan.

\section{Denaument (Penyelesaian)}

Tahap penyelesaian film Mursala bermula pada saat Inang memberitahukan Anggiat bahwasanya Uli ada di Jakarta dan Inang menyuruh Anggiat menjemputnya. Anggiat mulai kagum dengan Uli yang sedang mempresentasikan pulau Mursala ke rekan kerjanya. Anggiat mengajak Uli untuk menginap ke Apartementnya, Uli pun bertanya kepada Anggiat mengenai Clarisa. Anggiat mengatakan bahwa Clarisa tidak pernah bertemu dengan dirinya lagi, sehingga Anggiat tidak mengetahui kabar Clarisa lagi dan berkata "apa yang salah dengan hubungan ini". Uli pun mengatakan kepada Anggiat bahwa "kadang keinginan manusia tidak sesuai dengan takdir". Penyelesaian pada hubungan Anggiat dan Clarisa unhappy ending. Anggiat gagal mempertahankan hubungannya dengan Clarisa. Tetapi padascene-scene terakhir Anggiat terlihat mulai simpati dengan Uli dan mulai cari tahu mengenai dirinya. Berikut peristiwa-peristiwa tersebut:

Skenario film Mursala :scene 86-110

91. INT.APARTEMENT-MALAM

106. EXT.HALAMAN RUMAH ANGGIAT.SIANG

107. EXT.DERMAGA.SIANG

109. EXT.PERAHU.SIANG

Gambaran Anggiat telah mulai simpati dengan Uli dapat dilihat dari kutipan naskah berikut:

\section{EXT.DERMAGA.SIANG}

Ngomong-ngomong si Uli itu pernah punya pacar?, Dia sudah punya pacar ya?

Dari kutipan tersebut, terlihat Anggiat mulai ingin mencari tahu mengenai pacar Uli. Anggiat juga terlihat malu ketika menanyakannya kepada Sahat temannya. Capture pada scene terakhir ketika Anggiat pergi menemui Uli:

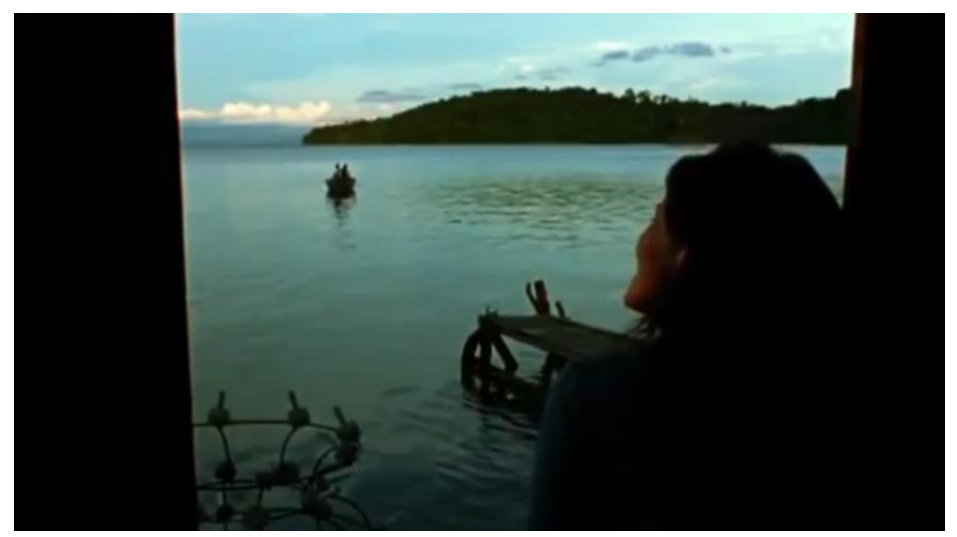

Gambar 6. Uli menunggu Sahat dan Anggiat (Sumber. Sri Wahyuni. Capture Film Mursala. 2017) 


\section{PENUTUP}

Struktur dramatik dari film Mursala karya Viva Westi terdiri dari tahap pengenalan tokoh yaitu Anggiat, Uli dan Clarisa. Peningkatan pada perumitan masalah terlihat pada saat ibu Anggiat mengetahui marga Clarisa. Konflik terjadi karena Anggiat tidak dapat melanjutkan hubungannya dengan Clarisa, sementara Inang berharap Anggiat menjalin hubungan dengan pariban-nya Uli. Klimaks yang merupakan terjadinya puncak konflik yang dialami oleh tokoh Anggiat dan Clarisa yang tidak dapat menemukan Solusi atas permasalahannya, meskipun Anggiat telah menemui penasehat adat.

Penurunan konflik terlihat pada saat Anggiat mulai bertanya kepada Uli mengenai pendapatnya tentang parna dan pariban. Clarisa yang tidak mau mengecewakan orang tua Anggiat memilih untuk pergi dan melanjutkan kuliahnya di luar negeri.Analisis struktur dramatik sebagai piranti pemahaman cerita narrative sekaligus untuk menyampaikan pesan-pesan yang tersembunyi didalam cerita tersebut mengenai adat Batak. Dalam film Mursala terdapat makna ketidakberdayaan seseorang dihadapan adat, meskipun seseorang tersebut sudah mencari solusinya namun pada akhirnya seseorang tersebut kalah oleh adat. Dengan kata lain adat pada masyarakat Batak masih sangat di pegang teguh di dalam masyarakat Batak.

\section{KEPUSTAKAAN}

[1] Harymawan, RMA. 1988. Dramaturgi. Bandung: CV Rosda.

[2] Juned, Sulaiman. 2016. Sulaiman Juned dalam Karya Teater "Lakon Jambo: Beranak Duri dalam Daging”. Jurnal Ekspresi Seni. Volume 18, No 2, https://journal.isipadangpanjang.ac.id/index.php/Ekspresi/article/view/94, 05 Agustus 2017

[3] Kridalaksana, Harimurti. 1998. Mongin Ferdinand de Saussure (1957-1913): Bapak Linguistik Modern dan Pelopor Strukturalisme. Yogyakarta: UGM Press

[4] Moleong, Lexy J. 2002. Metodologi Penelitian Kualitatif. Bandung: PT Remaja Rosdakarya.

[5] Pratista, Himawan. 2008. Memahami Film. Yogyakarta: Homerian Pustaka.

[6] Peransi, D.A. 2005. Film/Media/Seni. Jakarta: FFTV-IKJ Press.

[7] Sobur, Alex. 2001. Analisis Teks Media. Bandung:P.T Rosdakarya.

[8] -----------. 2002. Analisis Teks Media Sautu Analisis Untuk Analisis Wacana, Analisis Semiotik dan Analisis Framing. Bandung:P.T Rosdakarya. 